\title{
IDENTIFICATION AND ISOLATION OF ORF VIRUS FROM SHEEP IN THE REPUBLIC OF TUVA IN 2015
}

\section{D.V. YANZHIEVA' ${ }^{1}$, N.I. SAL'NIKOV'1, T.R. USADOV', S.P. ZHIVODEROV'1, L.K. SARYGLAR ${ }^{2}$, A.V. LUNITSIN1}

${ }^{1}$ All-Russian Institute of Veterinary Virology and Microbiology, Federal Agency of Scientific Organizations, 1, ul. Akademika Bakuleva, pos. Vol'ginskii, Petushinskii Region, Vladimir Province,601125 Russia, e-mail darima.yanzhieva.90@mail.ru, nikolai.salnikov2010@yandex.ru, usadov.tr@mail.ru, zhivoderov-serg@mail.ru, lunicyn@mail.ru;

${ }^{2}$ Tuvan State University, 36, ul. Lenina, Kyzyl, Tuva Republic, 667000 Russia, e-mail saryglar.1959@mail.ru Received October 4, 2016

\section{Abstract}

Orf is infectious disease of sheep and goats, characterized by lesions of mucosa of the oral cavity, skin of lips, head, mammary glands and limbs. The causal agent (virus of contagious ecthyma Orf virus) is a member of genus Parapoxvirus, subfamily Chordopoxvirinae, family Poxviridae. Genome of the Orf virus consists of linear double stranded DNA (138 kbp) and contains 132 open reading frames. Its antigenic structure is poorly understood, and strains are not serologically identical. That is why the investigation of novel isolates of Orf virus is actual. However, we are not aware of such research in Russia possibly due to rare outbreaks recognized. We first identified Orf virus in sheep from Tuva Republic and studied biological properties of the isolate. Disease of sheep, characterized by erythema, vesicles, pustules and scabs on ears and legs has been registered in August 2015 in Tuva Republic. The scabs were sampled for isolation and identification of the causative agent. For this result three lambs were experimentally infected with the scab suspension. The mucocutaneous borders of the lips along the labial commissures were scarified and inoculum was loaded by cotton swabs. The lip vesicles appeared at days 4-5 and then formed pustules and scabs. After 2 weeks the lesions healing occurred. The suspension of scabs from lips of infected lambs was used to inoculate sheep kidney cell culture. In 7 days post inoculation the cell monolayer was harvested for second passage. However, we did not observe specific cytopathic effect in the monolayers during these passages. The skin swabs from experimentally infected lambs were examined by Real-Time PCR in accordance to the protocol developed by G. Venkatesan et al. (2014), and Orf virus DNA was detected at days 7 to 28 post infection. We also detected Orf virus DNA in scabs from the infected lambs and in lysates of the monolayers harvested after second passage. The PCR test was positive for reference strain IA82 of Orf virus unlike other viruses (nodular dermatitis vaccine strain, sheep pox strains Mongolian and B5/96 or goatpox strain QA/A-04) that confirmed specificity of the PCR system. Its analytical sensitivity to detect Orf virus genomic DNA was $1.3 \pm 0.03 \mathrm{lg} \mathrm{TCD}_{50} / \mathrm{cm}^{3}$. Thus, the pathogen which caused the disease of sheep in Tuva Republic in 2015 was isolated from experimentally infected lambs using sheep kidney cell culture and identified as Orf virus.

Keywords: sheep, Orf virus, PCR, cell culture

Orf is an infectious disease, which is characterized by lesions of the oral mucosa, skin on lips, head, mammary glands and limbs forming nodules, vesicles, pustules and crusts, with a primary involvement of any single area of the body. The disease is widely spread around the world. In many countries with advanced sheep and goat breeding it is a stationary infection [1]. Its viral etiology was proven in experimentally, and a secondary role of the causative agent of necrobacillosis was established. The causal agent of contagious pustular dermatitis (Orf) is a contagious ecthyma virus (CEV; Orf virus, the genus Parapoxvirus, subfamily Chordopoxvirinae and family Poxviridae). Its virions are oval in shape with a size of 200$300 \times 140-170 \mathrm{~nm}$. The genome is represented by a linear double-stranded DNA molecule $(138 \mathrm{kbp})$ containing 132 open reading frames [2]. The virus causes disease in sheep, goats, chamois and tours of all ages, as well as in other clovenhoofed bovid animals. The disease is more severe in young animals. Humans get 
infected very rarely, mostly through contact with sick animals, and only if there are cuts and scratches on the skin. Lesions develop at the site of the virus penetration, usually on hands [3].

Sick animals are the main source of the infection, as the virus reproduces in their bodies. It is excreted with scabs, crusts and the flux from the oral cavity, which causes contamination of pastures, bird feeders, water, feed, sheepyards, inclosures, pens, and litter. The virus spreads to sheep coat, care items, and clothing of shepherds. Sheep can get infected when grazing on infected pastures, eating contaminated hay, feed, while taking water from contaminated watering sites, as well as through direct contact with sick animals [1, 4]. The disease is also spread by recovered virus carriers, which have been taken into good operating farms $[1,4,5]$, therefore, the virologic control on the animal movement is very important.

The antigen structure of CEV is not well understood, and not all the strains are serologically identical, and therefore the detection and investigation of its isolates is topical [3, 6-9]. Abroad, a conventional scheme for studying the properties of new $\mathrm{CEV}$ isolates includes pathogen isolation in ovine cell cultures, sequencing of the variable regions of the genome and phylogenetic analysis. This analysis has been performed for the strains obtained from goats in South Korea, India, the Himalayas and Taiwan [10-14]. The biological properties of the five strains of CEV isolated in goats were investigated (Texas, 2003-2004) [15]. Based on B2L gene sequencing [16], a method for the identification and phylogenetic analysis of the CEV isolates was characterized, which was then applied to the study of the strains from sheep in India and Brazil [17, 18]. The methods to identify the virus genome by PCR have been developed and validated [19-21], with a comparison of diagnostic features of various PCR protocols and CEV isolation in cell culture carried out [22]. In the domestic literature, there are no such papers that, apparently, is due to the lack of attention to the infection from animal owners and veterinary professionals, and, therefore, to a small number of reported outbreaks of contagious ecthyma in Russia.

We first isolated CEV from sheep in the Republic of Tyva, using the collected biological material to experimentally infect lambs, and studied the biological properties of the isolate.

The purpose of the work was to identify the pathogen that caused in 2015 the disease with symptoms of Orf in sheep in the Republic of Tyva.

Technique. Skin scabs from limbs and ears, sampled from the sheep with signs of Orf, were placed into the Eddington's liquid and transported in the cold box. The weighed portions of biomaterial was used to prepare a $10 \%$ suspension in phosphate-buffered saline $\left(137 \mathrm{mM} \mathrm{NaCl}, 2.7 \mathrm{mM} \mathrm{KCl}, 10 \mathrm{mM} \mathrm{Na}{ }_{2} \mathrm{HPO}_{4}\right.$, $\left.1.76 \mathrm{mM} \mathrm{NaH}{ }_{2} \mathrm{PO}_{4}, \mathrm{pH} 7.4\right)$ at a ratio of $1: 9(\mathrm{w} / \mathrm{v})$ and homogenized in a porcelain mortar. The suspension was clarified by centrifugation $(3 \mathrm{~min}$ at $7,000 \mathrm{rpm}$ ). The biological properties of the virus were studied by the infection of three lambs in a vivarium using the suspension of skin scabs from the limbs of sick animals. The infectious inoculum was loaded with a cotton swab on the scarified surface of the lips on the mucocutaneous borders. Clinical examination of animals was carried out daily, with obtaining swabs from the sites of virus introduction.

The virus was isolated in a passaged culture of ovine kidney cells (the PO-VNIIVViM line; the museum of the All-Russian Research Institute of Veterinary Virology and Microbiology), grown in flasks with the landing area of $150 \mathrm{~cm}^{2}$. The suspension of scabs from infected animals was passed through a $45 \mu \mathrm{m}$ filter (Millipore, USA), then diluted with Eagle's MEM with antibiotics $(50 \mu \mathrm{g} / \mathrm{ml}$ gentamicin, $2.5 \mu \mathrm{g} / 1$ Amphotericin B) at a ratio of 1:1. Next, $1 \mathrm{ml}$ of 
suspension was added to cell culture flasks which were then kept for 30 minutes in the MCO-18AC CO 2 incubator (Sanyo Electric Co., Ltd, Japan) at $37{ }^{\circ} \mathrm{C}$. The culture medium was decanted, then $10 \mathrm{ml}$ Eagle's MEM was added, containing $2 \%$ fetal calf serum (Biolot, Russia), and cultured under the same conditions for 7 days. Then the monolayer was frozen and thawed thrice and used for the $2^{\text {nd }}$ passage (there were no subsequent passages).

The samples were tested for the Orf virus DNA using the real-time PCR. PCR was performed on a Rotor Gene 6000 thermocycler (Corbett Research Pty, $\mathrm{Ltd}$, Australia) according to the following protocol: $10 \mathrm{~min}$ at $95{ }^{\circ} \mathrm{C}-$ a preliminary denaturation; $30 \operatorname{secs} 95{ }^{\circ} \mathrm{C}, 1 \mathrm{~min}$ at $60{ }^{\circ} \mathrm{C}-$ detection by "Green" channel. The reaction mixture contained 10 pmol of each primer, 3 pmol of a fluorescent probe, $2.5 \mu \mathrm{l}$ of $10 \times$ DNA buffer, $10 \mathrm{mM}$ triphosphates mixture and 1.5 Taq units of recombinant DNA polymerase (Thermo Fisher Scientific, USA). OV RT-F (5'-TACACGGAGTTGGCCGTGATCTTGTA-3') and OV RT-R (5'-CGCCAA-GTACAAGAAGCTGATGA-3') primers, and a hybridization probe OV Probe (5' - [FAM]TGCATCGAGTTGTAGATCTCGCGGT[BHQ1]-3') developed in 2014 [23] were used. The system specificity was tested with DNA samples of the viruses of nodular dermatitis, sheep pox, goat pox and Orf (The VNIIVViM Collection of Microorganisms), the test analytical sensitivity was controlled using 10-fold dilutions of the primary cell culture of lamb synovial membrane (VNIIVViM Museum) infected with the Orf virus. The values with the relative standard deviation at \pm 0.03 are given for the titres [24].

Results. In August 2015, in the Buy-Khol APC of the Bay-Tal sumon
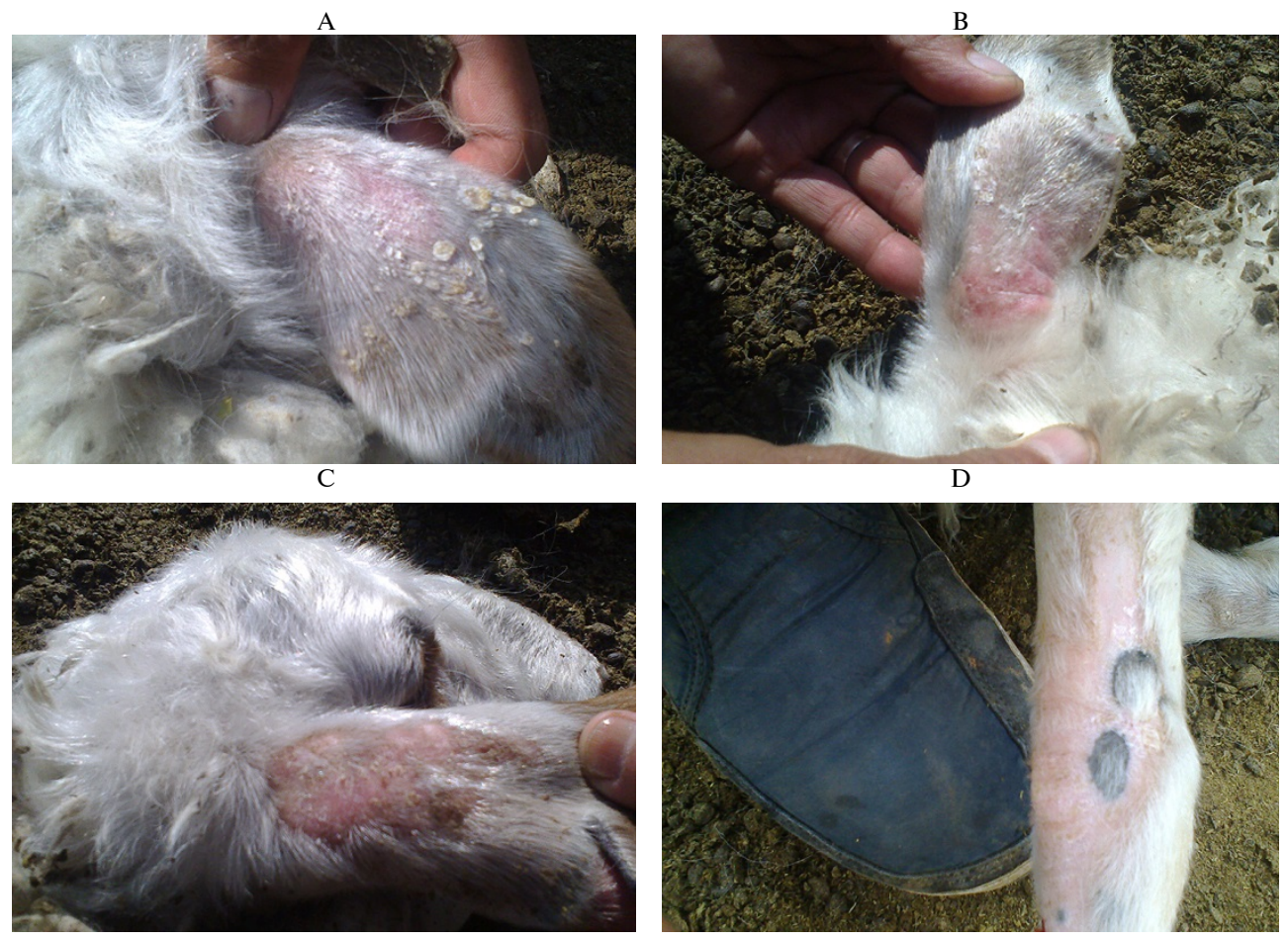

The clinical signs of Orf in sheep: A, B - scabs on the skin of ears, C - skin pustules on the ears, D - pustules on the leg skin (Republic of Tyva, 2015).

(Erzin district, Republic of Tyva) in sheep and lambs born in late March-early April, a disease was reported involving lesions of the skin in the form of scabs on the limbs, ears and nose. In lambs, the redness of the skin around the ears was first observed, then it appeared on the limbs and in the nostrils, the hair fell out, 
and the formation of vesicles and long healing ulcers was seen (Figure). In the experimental infection of healthy animals with the biomaterial from sick animals, on day 4-5 at the site of virus introduction vesicles appeared that turned into pustules 1 day after. Drying out, pustules formed grayish-brown scabs. Two weeks after the experimental infection lesions healed.

After two passages (for 7 days each) specific cytopathic effect of the Orf virus in the primary PO-VNIIVViM cell culture was not found. The virus reproduction in cell culture was confirmed by the identification of its genomic DNA by real-time PCR in the lysate of the cell monolayer after the $2^{\text {nd }}$ passage (7 days). A used system of oligonucleotide primers and Taq-man probe are complementary to the DNA polymerase gene of this virus [9]. When studying the reference DNA samples of CEV (IA82 strain), nodular dermatitis (vaccine strain), sheep pox (Mongolian and B5/96 strains), goat pox (OK/A-04 strain), positive results were obtained only with DNA of CEV that confirmed the system specificity. The lysate of the PO-VNIIVViM cell culture infected with CEV (2 ${ }^{\text {nd }}$ passage) was PCR positive. It means that only samples of CEV DNA were PCR positive, additionally indicating the specificity of the primers and probes used. The highest dilution of the culture material containing CEV (the reference strain IA82, the infectious activity of $\left.5.3 \pm 0.03 \mathrm{lg} T C D_{50} / \mathrm{cm}^{3}\right)$, for which a positive PCR result was obtained, was $10^{-4}$ (Table 1). Therefore, the analytical sensitivity of real-time PCR to detect the Orf virus genome was $1.3 \pm 0.03 \mathrm{lg} \mathrm{TCD}_{50} / \mathrm{cm}^{3}$.

1. The analytical sensitivity of real-time PCR in detecting Orf virus genome

\begin{tabular}{ccc}
\hline Dilution & Viral titer, $\lg \mathrm{TCD}_{50} / \mathrm{cm}^{3}$ & Threshold cycle \\
\hline $10^{-1}$ & $4.3 \pm 0.03$ & 17.81 \\
$10^{-2}$ & $3.3 \pm 0.03$ & 22.09 \\
$10^{-3}$ & $2.3 \pm 0.03$ & 25.59 \\
$10^{-4}$ & $1.3 \pm 0.03$ & 30.46 \\
$10^{-5}$ & $0.3 \pm 0.03$ & $\mathrm{~N} / \mathrm{A}$ \\
\hline
\end{tabular}

$\mathrm{N}$ ot e. Threshold cycle is a cycle in which the fluorescence curve intersects the threshold line. (Table 2). Testing of pustules formed at the site of the virus infection, as well as the culture material, also gave positive results ( $\mathrm{Ct}$ 8.1-9.3).

2. The real-time PCR threshold cycles for Orf virus genome detection in oral smears after experimental infection

\begin{tabular}{l|c|c|c}
\hline \multicolumn{1}{c|}{ Day after infection } & Lamb 1 & Lamb 2 & Lamb 3 \\
\hline 7 & 18.23 & 19.32 & 18.51 \\
14 & 25.98 & 22.27 & 24.21 \\
21 & 35.59 & 29.21 & 30.43 \\
28 & Negative & Negative & Negative \\
\multicolumn{2}{l}{ N o t e. Threshold cycle is a cycle in which the fluorescence curve inter- } \\
sects the threshold line.
\end{tabular}
induced vesicular-pustular rash at the site of viral inoculation (on the mucocutaneous border of the lips). The causative agent was isolated from cutaneous scabs in the experimentally infected animals using ovine kidney cell line culture and identified by real-time PCR analysis.

\section{REFEREN CES}

1. Kolomytsev A.A., Zakutski N.I., Guzalova A.G., Mikolaichuk S.V., Morgu nov Yu.P. Veterinarnaya patologiya, 2008, 4: 31-37 (in Russ.).

2. Delhon G., Tulman E.R., Afonso C.L., Lu Z., de la Concha-Bermejillo A., Leh mkuhl H.D., Piccone M.E., Kut ish G.F., Rock D.L. Genomes of the parapoxviruses Orf virus and bovine papular stomatitis virus. J. Virol., 2004, 78(1): 168-177 (doi: 
10.1128/JVI.78.1.168-177.2004).

3. B a y ind i r Y., B a y rakt a r M., Karadag N., Ozcan H., Kayabas U., Ot lu B., D u rmaz R., Doganay M. Investigation and analysis of a human orf outbreak among people living on the same farm. New microbiologica, 2011, 34: 37-43.

4. Hosamani A., Scagliarini A., Bhanuprakash V., Mc Innes C.J., Singh R.K. Orf: an update on current research and future perspectives. Expert Review on Anti-infective Therapy, 2009, 7(7): 879-893 (doi: 10.1586/eri.09.64).

5. Bhanuprakash V., Venkatesan G., Balamurugan V., Hosamani M., Yogisharadhya R., Chauhan R.S., Pande A., Mondal B., Singh R.K. Pox outbreaks in sheep and goats at Makhdoom (Uttar Pradesh), India: evidence of sheep pox virus infection in goats. Transbound. Emerg. Dis., 2010, 57(5): 375-382 (doi: 10.1111/j.18651682.2010.01158.x).

6. Abubankr M.I., Abu-Elzein E.M., Housawi F.M., Abdelrahman A.O., Fadlallah M.E., Naye 1 M.N., Adam A.S., Moss S., Forrester N.L., Coloyan E., Ga me et A., Al-Afale q A.I., Gould E.A. Pseudo cow poxvirus: the etiological agent of contagious ecthyma (Auzdyk) in camels (Camelus dromedarius) in the Arabian peninsula. Vector Borne Zoonotic Diseases, 2007, 7(2): 257-260 (doi: 10.1089/vbz.2006.0627).

7. Abdel rabman K., S o li man H. Molecular and virological studies on contagious pustular dermatitis isolates from Egyption sheep and goats. Research in Veterinary Science, 2010, 89(2): 290-294 (doi: 10.1016/j.rvsc.2010.02.019).

8. Wis e L.M., S avory L.J., Dryden N.H., Whelan E.M., Fle ming S.B., Me rce $\mathrm{r}$ A.A. The development of oral lesions in lambs naturally infected with orf virus. Veterinary Journal, 2007, 174(3): 663-664 (doi: 10.1016/j.tvjl.2006.10.024).

9. Venkatesan G., B a la murugan V., B hanuprak a h V. TaqMan based real-time duplex PCR for simultaneous detection and quantitation of Capri pox and Orf virus genomes in clinical samples. J. Virol. Methods, 2014, 201: 44-50 (doi: 10.1016/j.jviromet.2014.02.007).

10. O e m J.-K., Chung J.-Y., K i m Y.-J., Le e K.-K., K i m S.-H., Jung B.-Y., Hy $\mathrm{u} \mathrm{n}$ B.-H. Isolation and characterization of orf viruses from Korean black goats. J. Vet. Sci., 2013, 14(2): 227-230 (doi: 10.4142/jvs.2013.14.2.227).

11. Bora D.P., Barman N.N., Das S.K., B hanuprakash V., Yog isharadhya R., Venkatesan G., Kumar A., Rajbongshi G., Khatoon E., Chakraborty A., $\mathrm{Bujarb}$ a r a h K.M. Identification and phylogenetic analysis of orf viruses isolated from outbreaks in goats of Assam, a northeastern state of India. Virus Genes, 2012, 45: 98-104 (doi: 10.1007/s11262-012-0740-y).

12. Chan K.W., Li n J.W., Le e S.H., Lia o C.J., Tsai M.C., Hsu W.L., Wong M.L., $\mathrm{S}$ hi h H.C. Identification and phylogenetic analysis of orf virus from goats in Taiwan. Virus Genes, 2007, 35: 705-712 (doi: 10.1007/s11262-007-0144-6).

13. Mondal B., Bera A.K., Hos mani M., Te mb hurne P.A., Bandyopad hy a $y$ S.K. Detection of orf virus from an outbreak in goats and its genetic relation with other parapoxviruses. Veterinary Research Community, 2006, 30: 531-539 (doi: 10.1007/s11259-006-3270-z).

14. Hosamani M., Yadav S., Ka 11 e s h D.J., Monda 1 B., B han u p raka h V., $\mathrm{S}$ i $\mathrm{n} \mathrm{g} \mathrm{h} \mathrm{R.K.} \mathrm{Isolation} \mathrm{and} \mathrm{characterization} \mathrm{of} \mathrm{an} \mathrm{Indian} \mathrm{orf} \mathrm{virus} \mathrm{from} \mathrm{goats.} \mathrm{Zoonoses} \mathrm{Public}$ Health, 2007, 54: 204-208 (doi: 10.1111/j.1863-378.2007.01046.x).

15. M u s s e $\mathrm{r}$ J.M.B., T a y 1 o r C.A., G u o J., T i z a r d I.R., W a 1 k e r J.W. Development of a contagious ecthyma vaccine for goats. Am. J. Vet. Res., 2008, 69: 1366-1370 (doi: 10.2460/ajvr.69.10.1366).

16. Hos a mani M., B han u p rak a s h V., S c aglia ri n i A., S i ngh R.K. Comparative sequence analysis of major envelope protein gene (B2L) of Indian orf viruses isolated from sheep and goats. Vet. Microbiol., 2006, 116: 317-324 (doi: 10.1016/j.vetmic.2006.04.028).

17. Venkatesan G., B a lamurugan V., Bora D.P., Yogisharadhya R., $\mathrm{Prabhu}$ M., B ha n p r a k s h V. Sequence and phylogenetic analyses of an Indian isolate of orf virus from sheep. Veterinaria Italiana, 2011, 47(3): 323-332.

18. A b r a h го J.S., C a m p os R.K., Trindade G.S., Gue des M.I., L o b a t o Z.I., M a z u r C., F e r re i r a P.C., B o n jardi m C.A., K roon E.G. Detection and phylogenetic analysis of orf virus from sheep in Brazil: a case report. Virol. J., 2009, 6: 47 (doi: 10.1186/1743-422X-6-47).

19. C ha n K.W., H s u W.L., W a ng C.Y., Y ang C.H., Li n F.Y., C hulak a s i a $\mathrm{n}$ S., W o n g M.L. Differential diagnosis of orf viruses by a single-step PCR. J. Virol. Methods, 2009, 160(1-2): 85-89 (doi: 10.1016/j.jviromet.2009.04.025).

20. Gallina L., Dal Pozzo F., Mc Innes C.J., Cardeti G., Guercio A., Battilani M., $\mathrm{C}$ i u 11 i S., S c a g 1 i a r i n i A. A real-time PCR assay for the detection and quantification of orf virus. J. Virol. Methods, 2005, 134: 140-145 (doi: 10.1016/j.jviromet.2005.12.014).

21. Nitsche A., Buttner M., Wilhelm S., Pauli G. Meyer H. Real-Time PCR detection of parapoxvirus DNA. Clin. Chem., 2006, 52(2): 316-319 (doi: 10.1373/clinchem.2005.060335).

22. Kottaridi C., Nomikou K., Lelli R., Markoulatos P., Mangana O. Laborato- 
ry diagnosis of contagious ecthyma: comparison of different PCR protocols with virus isolation in cell culture. J. Virol. Methods, 2006, 134: 119-124 (doi: 10.1016/j.jviromet.2005.12.005).

23. Venkatesan G., B a la murugan V., B hanuprakas h V. TaqMan based real-time duplex PCR for simultaneous detection and quantitation of Capri pox and Orf virus genomes in clinical samples. J. Virol. Methods, 2014, 201: 44-50 (doi: 10.1016/j.jviromet.2014.02.007).

24. L a k i n G.F. Biometriya [Biometry]. Moscow, 1990 (in Russ.). 